\title{
Comparative Studies on the Nutrient Levels of Vermicomposts by Eisenia fetida and Eudrilus eugeniae and Their Effects on Vigna radiata
}

\author{
P.Porkodi ${ }^{1}$, M.Amruththa ${ }^{2}$ \\ ' (Department of Biotechnology, Mother Teresa women's university, India) \\ ${ }^{2}$ (Department of Biochemistry, Mother Teresa women's university, India)
}

\begin{abstract}
This present study was designed to convert the waste products present in the environment into a valuable product by an ecofriendly approach. Vermicomposting is a cost effective, pollution free process by use of earthworms. A comparative study was carried out to convert cow dung, leaf litter, and market waste into vermicompost and the efficiency of the two earthworm species were tested. Both the species shows the degradation of substrates and convert them into nutrient rich vermicompost. The effect of these vermicompost was tested on the growth of Vigna radiate((Green gram ,Mung bean), their percentage of germination, vigor index, chlorophyll content, phytochemicals increased compared to control. Among the different substrate used cow dung vermicompost is more suitable for plant growth than market waste and leaf litter vemicompost. On the basis of chemical analysis the observation indicated that Eisenia fetida is superior in performance over Eudrilus eugeniae.
\end{abstract}

Key words: Nutrient level, Vermicompost, Eisenia fetida, Eudrilus eugeniae, Vigna radiata.

\section{Introduction}

India has crossed 1.27 billion of human population, it parallels with the dumping of wastes. The waste is dumped in wastelands, agricultural lands in and around dwelling places, which forms the breeding places for mosquitoes, insects. Problems like pollution, disease outbreak, and environmental health hazards arise. To save earth and to prevent these problems, wastes can be converted into organic fertilizer to fulfill the needs of farmers. In recent years disposal of organic wastes from various sources like domestic, agricultural and industrial has caused serious environmental hazards and economic problems [1].

In today's era, heavy doses of chemical fertilizers and pesticides decreased soil fertility and causes health problems to the consumers [3].

Vermicomposting is a simple biotechnological process of composting in which certain species of earthworms are used to enhance the process of wastes conversion and produce a better end product [11].Vermicompositng utilizes earthworms as bioreactors to biodegrade organic wastes to humus substrates as solid wastes derived from agro based and food processing industries and other industries and agricultural residues have been used for vermicomposting[8].Vermicomposting is an easy way to make a positive environment impact by reducing the amount of green waste that finds its way into landfills incinerators and sometimes the ocean. The resulting nutrient rich compost end product is an environmentally sound amendment to enrich soil for plant growth[23].

Vermicompost is the microbial composting of organic waste through earthworm activity to form organic fertilizer which contain higher levels of organic matter, organic carbon, total and available $\mathrm{N}, \mathrm{P}, \mathrm{K}$ and micronutrients, microbial and enzyme activitie [15].

\section{Preparation Of Compost From Various Substrates \\ Experimental Design}

\section{Materials And Methods}

The experiments were carried out in the farm lans of Cumbum Taluk, Theni District. A total of 6 cement tanks were used and kept in 2 sets. 3 tanks for Eisenia fetida and 3 for Eudrilus eugeniae. $50 \mathrm{~kg}$ of cow dung, leaf litter, and market waste were added individually for each set. 72 earthworms of each species were introduced separately on each set. The water was sprinkled in each tanks and moisture was maintained throughout the experimentation.

\section{Preparation Of The Compost}

First the compost was dried in the air and sieved through a $2 \mathrm{~mm}$ sieve to remove unwanted things. The entire dry sample was crushed with mortar and pestle. The crushed sample was again screened through a $2 \mathrm{~mm}$ sieve and about $250 \mathrm{~kg}$ of the well prepared sample was kept for analysis. 


\section{Analysis Of Biochemical And Biological Properties}

The samples were taken from the different sets at the initial and at the $90^{\text {th }}$ day of vermicomposting. The physical property like $\mathrm{pH}$ were determined by [21]method. Organic carbon was estimated by Walky and black method, available nitrogen, potassium, phosphorus were estimated respectively by Microkjeldhal method,[5], Flame photometric method. Total microbial populations of bacteria, fungi and actinomycetes from the substrates were determined by [6]

\section{Measurement Of Growth Parameters And Phytochemical Analysis}

The germination studies of mung bean seeds were carried by the methods of [27] The measurement of various morphological growth parameters such as root length, shoot length, vigour index, dimensions of leaves was taken within the time interval of 10,20,30 days and biochemical constituents such as chlorophyll content were estimated by the methods of [2] and phytochemical contents were evaluated by the methods of [14]

\section{Results And Discussion}

In the present study different substrate such as cow dung, leaf litter, and market waste were converted into vermicompost and the efficacy of the two earthworm species Eisenia fetida, Eudrilus eugeniae were tested. The physical, chemical, biological factors of these obtained vermicompost were determined. Then the effect of these vermicompost in the growth of Vigna radiata was carried out.

\section{Analysis Of Biochemical And Biological Properties}

Initially the $\mathrm{pH}$ values of all these organic wastes was observed as high, with the progress of vermicomposting the $\mathrm{pH}$ value was around neutral. These results were in accordance with [9] The decrease may be due to carbondioxide and organic acids produced during microbial metabolism. [24], reported that the $\mathrm{pH}$ around neutrality provides valuable information about the decomposition stage of organic matter during the humification process.

The total nitrogen content of vermicompost of the two earthworm species in all the three different substrates was higher than the initial level. The increasing trend of $\mathrm{N}$ in the vermicomposts produced by the earthworm species in the present study similar with the findings of earlier reports[18].

The total phosphorus was higher in all vermicompost harvested at the end of the experiment compared to that of the initial substrate The enhanced $\mathrm{P}$ level in vermicompost suggests phosphorous mineralization during the process. The worms during vermicomposting converted the insoluble $\mathrm{P}$ into soluble forms with the help of $\mathrm{P}$ solubilizing microorganisms through phosphatases present in the gut, making it more available to plants [25]

The level of potassium increased in all treatments. The present findings were supported by [7] demonstrated that higher $\mathrm{K}$ concentration in the end product prepared from sewage sludge. The microorganisms present in the worm's gut probably converted insoluble $\mathrm{K}$ into the soluble form by producing microbial enzymes [20].The C: $\mathrm{N}$ ratio of different substrates degraded by both Eisenia fetida,Eudrilus eugeniae had been reduced significantly to lower level.

The results of the present study are in accordance with previous reports which shows that combustion of carbon by the earthworms during respiration, production of mucus and nitrogen excrements, increases the levels of nitrogen and lowers the $\mathrm{C} / \mathrm{N}$ ratio. This might be the reason for the decrease of $\mathrm{C}: \mathrm{N}$ ratio in the compost. (Table 1).The data are also supported by [15], Bacteria might have multiplied fast in vermicompost so long the sufficient moisture is present. The microorganism including bacteria, fungi, yeasts, actinomycetes are capable of producingplant growth hormones and plant growth regulators such as auxins,gibberlins,cytokinins, ethylene and absicisic acid in appreciable quantities. The present study shows that there is a slight decrease in level of fungi. Similarly, [16] ,reported that earthworm inevitably consumes soil microbes during ingestion of the organic substrate and extracts nitrogen from microbes especially from fungi. This may be the reason for less number of fungi in vermicompost samples. ( Table 2)

\section{Measurement Of Growth Parameters And Phytochemical Analysis}

The maximum germination was obtained in cow dung vermicompost (96\%), the germination percentage of market waste vermicompost was $(92 \%)$, the germination percentage of leaf litter vermicompost was $(88 \%)$ which was more than control $(76 \%)$. This was similar to the work of [22] which shows that the application of vermicompost gave higher germination growth and yield of beans compared with control. According to the experiments maximum growth of Vigna radiata was recorded in composted cow dung treated with Eisenia fetida followed by composted cow dung treated with Eudrilus eugeniae compared to control[4]) supported that the positive effects of vermicompost on the tested plants due to nutrients present in the worm cast are readily soluble in water for the uptake of plants. The highest vigour index was observed in cowdung + 
eisenia fetida (3465.6) in 30 days. It was concluded that in all Treatments showed higher vigour index compared to control(2044.4) (table 3) .

The present study was supported by canellas et al., 2011, in maize plants the elongation And proliferation of secondary roots due to the phytohormone auxin in the humic substances resulted in increased total length and root surface area(table 4). Chlorophyll content in the leaves of vigna radiata increased in all treatments when compared to control which shows that not only the physical characteristics of plant changed but also the leaf chlorophyll content enhanced with the application of vermicompost due to nutrients such as $\mathrm{n}, \mathrm{p}, \mathrm{k}$, $\mathrm{mg}$, fe and cu which are readily available through vermicompost are used in the formation of chlorophyll which is required for light harvesting and subsequent conversion into chemical energy [13] (table 5).

The phytochemical contents of plants increased in plants treated with vermicompost than the control .Phytochemicals form part of the natural plant defense system against infection and microbial invasions [19],supported that the application of vermicompost with or without inorganic fertilizers for maximum and effective phytochemicals production for plant defense and improved quality of the edible parts

IV. Figures And Tables

Table 1: Comparative Study Of Nutrient Levels Of Vermicompost

\begin{tabular}{|c|c|c|c|c|c|c|c|c|c|}
\hline \multirow{2}{*}{ Parameters } & \multicolumn{3}{|c|}{ COW DUNG } & \multicolumn{3}{c|}{ LEAF LITTER } & \multicolumn{3}{c|}{ MARKET WASTE } \\
\cline { 2 - 10 } & Initial & $\begin{array}{c}\text { Eisenia } \\
\text { fetida }\end{array}$ & $\begin{array}{c}\text { Eudrilus } \\
\text { eugeniae }\end{array}$ & Initial & $\begin{array}{c}\text { Eisenia } \\
\text { fetida }\end{array}$ & $\begin{array}{c}\text { Eudrilus } \\
\text { eugeniae }\end{array}$ & Initial & $\begin{array}{c}\text { Eisenia } \\
\text { fetida }\end{array}$ & $\begin{array}{c}\text { Eudrilus } \\
\text { eugeniae }\end{array}$ \\
\hline $\mathbf{p H}$ & 8.3 & 7.0 & 7.1 & 8.5 & 7.2 & 7.2 & 8.89 & 7.1 & 7.2 \\
\hline $\mathbf{C}(\%)$ & 20.2 & 12.17 & 12.23 & 44.54 & 35.91 & 36 & 49.9 & 21.2 & 23 \\
\hline $\mathbf{N}(\%)$ & 0.5 & 0.66 & 0.64 & 0.74 & 1.12 & 1.1 & 0.62 & 0.9 & 0.89 \\
\hline $\mathbf{P ( \% )}$ & 0.11 & 0.21 & 0.19 & 0.12 & 0.26 & 0.23 & 0.71 & 0.8 & 0.76 \\
\hline $\mathbf{K}(\%)$ & 0.60 & 0.63 & 0.62 & 0.42 & 0.48 & 0.47 & 0.72 & 1.03 & 0.98 \\
\hline $\mathbf{C : N}$ & 40.4 & 18.43 & 19.1 & 60.1 & 32.06 & 32.72 & 80.48 & 23.55 & 25.84 \\
\hline
\end{tabular}

Table 2: Comparative Study Of Microbial Populations

\begin{tabular}{|c|c|c|c|c|}
\hline \multirow[b]{2}{*}{$\begin{array}{c}\text { MICRO } \\
\text { ORGANISM }\end{array}$} & \multicolumn{4}{|c|}{ COW DUNG } \\
\hline & $\begin{array}{c}\text { Initial } \\
\text { Eisenia } \\
\text { fetida }\end{array}$ & $\begin{array}{c}\text { Final } \\
\text { Eisenia } \\
\text { fetida }\end{array}$ & $\begin{array}{c}\text { Initial } \\
\text { Eudrilus } \\
\text { eugeniae }\end{array}$ & $\begin{array}{c}\text { Final } \\
\text { Eudrilus } \\
\text { eugeniae }\end{array}$ \\
\hline $\begin{array}{c}\text { Bacteria } \\
\times 10^{6} \mathrm{CFU}\end{array}$ & 112 & 129 & 101 & 119 \\
\hline $\begin{array}{c}\text { Fungi } \\
\mathrm{X} 10^{3} \mathrm{CFU}\end{array}$ & 57 & 45 & 49 & 36 \\
\hline $\begin{array}{c}\text { Actino } \\
\text { mycetes } \\
\text { X } 10^{3} \mathrm{CFU}\end{array}$ & 22 & 39 & 17 & 32 \\
\hline \multirow[b]{2}{*}{$\begin{array}{c}\text { MICRO } \\
\text { ORGANISM }\end{array}$} & \multicolumn{4}{|c|}{ MARKET WASTE } \\
\hline & $\begin{array}{c}\text { Initial } \\
\text { Eisenia } \\
\text { fetida } \\
\end{array}$ & $\begin{array}{c}\text { Final } \\
\text { Eisenia } \\
\text { fetida } \\
\end{array}$ & $\begin{array}{c}\text { Initial } \\
\text { Eudrilus } \\
\text { eugeniae } \\
\end{array}$ & $\begin{array}{c}\text { Final } \\
\text { Eudrilus } \\
\text { eugeniae } \\
\end{array}$ \\
\hline $\begin{array}{c}\text { Bacteria } \\
\text { X } 10^{6} \mathrm{CFU}\end{array}$ & 89 & 107 & 76 & 98 \\
\hline $\begin{array}{c}\text { Fungi } \\
\mathrm{X} 10^{3} \mathrm{CFU} \\
\end{array}$ & 34 & 27 & 29 & 23 \\
\hline $\begin{array}{c}\text { Actino } \\
\text { mycetes } \\
\times 10^{3} \mathrm{CFU}\end{array}$ & 13 & 22 & 9 & 18 \\
\hline \multirow{2}{*}{$\begin{array}{c}\text { MICRO } \\
\text { ORGANISM }\end{array}$} & \multicolumn{4}{|c|}{ LEAF LITTER } \\
\hline & $\begin{array}{c}\text { Initial } \\
\text { Eisenia } \\
\text { fetida } \\
\end{array}$ & $\begin{array}{c}\text { Final } \\
\text { Eisenia } \\
\text { fetida }\end{array}$ & $\begin{array}{c}\text { Initial } \\
\text { Eudrilus } \\
\text { eugeniae }\end{array}$ & $\begin{array}{c}\text { Final } \\
\text { Eudrilus } \\
\text { eugeniae }\end{array}$ \\
\hline $\begin{array}{c}\text { Bacteria } \\
\times 10^{6} \mathrm{CFU}\end{array}$ & 78 & 91 & 71 & 83 \\
\hline $\begin{array}{c}\text { Fungi } \\
\times 10^{3} \mathrm{CFU} \\
\end{array}$ & 26 & 18 & 17 & 11 \\
\hline $\begin{array}{c}\text { Actino } \\
\text { mycetes } \\
\times 10^{3} \mathrm{CFU}\end{array}$ & 6 & 10 & 5 & 8 \\
\hline
\end{tabular}


Comparative Studies On The Nutrient Levels Of Vermicomposts By Eisenia ....

Table 3: Comparative Study Of Effect Of Vermicompost On Vigour Index

\begin{tabular}{|l|c|c|c|}
\hline \multirow{2}{*}{\multicolumn{1}{c|}{ TREATMENT }} & \multicolumn{3}{c|}{ VIGOUR INDEX } \\
& \multicolumn{3}{c|}{ NUMBER OF DAYS } \\
\cline { 2 - 4 } & $\mathbf{1 0}$ & $\mathbf{2 0}$ & $\mathbf{3 0}$ \\
\hline CONTROL & 395.2 & 1124.8 & 2044.4 \\
\hline COW DUNG+ Eisenia fetida & 806.4 & 1804.8 & 3465.6 \\
\hline COW DUNG+ Eudrilus eugeniae & 768 & 1766.4 & 3321.6 \\
\hline LEAF LITTER+ Eisenia fetida & 536.8 & 1399.2 & 2578.4 \\
\hline LEAF LITTER+ Eudrilus eugeniae & 492.8 & 1372.8 & 2490.4 \\
\hline MARKET WASTE + Eisenia fetida & 653.2 & 1600.8 & 2990 \\
\hline MARKETWASTE+Eudrilus eugeniae & 625.6 & 1554.8 & 2934.8 \\
\hline
\end{tabular}

Table 4 : Effect Of Vermicompost On Dimensions Of Leaves

\begin{tabular}{|l|c|c|c|c|c|c|}
\hline \multirow{2}{*}{ TREATMENT } & \multicolumn{3}{|c|}{ LEAF LENGTH (cm) } & \multicolumn{3}{c|}{ LEAF WIDTH (cm) } \\
\cline { 2 - 7 } & \multicolumn{3}{|c|}{ NUMBER OF DAYS } & \multicolumn{3}{c|}{ NUMBER OF DAYS } \\
\cline { 2 - 7 } CONTROL & $2.2 \pm 0.5$ & $3.3 \pm 0.4$ & $6.3 \pm 0.2$ & $0.8 \pm 0.5$ & $2.1 \pm 0.4$ & $2.9 \pm 0.3$ \\
\hline $\begin{array}{l}\text { COW DUNG+ } \\
\text { Eisenia fetida }\end{array}$ & $3.8 \pm 0.6$ & $5.9 \pm 0.1$ & $8.3 \pm 0.3$ & $2.4 \pm 0.4$ & $3.5 \pm 0.2$ & $4.9 \pm 0.1$ \\
\hline $\begin{array}{l}\text { COW DUNG+ } \\
\text { Eudrilus eugeniae }\end{array}$ & $3.6 \pm 0.6$ & $5.6 \pm 0.2$ & $8 \pm 0.3$ & $2.2 \pm 0.3$ & $3.3 \pm 0.1$ & $4.5 \pm 0.5$ \\
\hline $\begin{array}{l}\text { LEAF LITTER+ } \\
\text { Eisenia fetida }\end{array}$ & $2.8 \pm 0.6$ & $4 \pm 0.1$ & $7.1 \pm 0.5$ & $1.3 \pm 0.2$ & $2.5 \pm 0.3$ & $3.2 \pm 0.2$ \\
\hline $\begin{array}{l}\text { LEAF LITTER+ } \\
\text { Eudrilus eugeniae }\end{array}$ & $2.6 \pm 0.1$ & $3.8 \pm 0.4$ & $6.7 \pm 0.2$ & $1.1 \pm 0.1$ & $2.3 \pm 0.2$ & $3.1 \pm 0.6$ \\
\hline $\begin{array}{l}\text { MARKET WASTE+ } \\
\text { Eisenia fetida }\end{array}$ & $3.3 \pm 0.1$ & $4.9 \pm 0.5$ & $7.7 \pm 0.3$ & $1.7 \pm 0.5$ & $2.9 \pm 0.6$ & $3.8 \pm 0.4$ \\
\hline $\begin{array}{l}\text { MARKETWASTE+ } \\
\text { Eudrilus eugeniae }\end{array}$ & $3 \pm 0.2$ & $4.7 \pm 0.6$ & $7.5 \pm 0.4$ & $1.6 \pm 0.3$ & $2.8 \pm 0.2$ & $3.5 \pm 0.5$ \\
\hline
\end{tabular}

Table 5: Effect Of Vermicompost On Chlorophyll Content

\begin{tabular}{|l|c|}
\hline \multicolumn{1}{|c|}{ TREATMENT } & $\begin{array}{c}\text { CHLOROPHYLL } \\
\text { (mg/g fresh weight) }\end{array}$ \\
\hline CONTROL & 2.51 \\
\hline COW DUNG+ Eisenia fetida & 3.78 \\
\hline COW DUNG+ Eudrilus eugeniae & 3.75 \\
\hline LEAF LITTER+ Eisenia fetida & 2.85 \\
\hline LEAF LITTER+ Eudrilus eugeniae & 2.78 \\
\hline MARKET WASTE + Eisenia fetida & 3.05 \\
\hline MARKETWASTE+Eudrilus eugeniae & 3.00 \\
\hline
\end{tabular}

\section{Conclusion}

It was concluded that earthworms are capable of working hard to convert all the organic waste into manure. Earthworms can serve as tool to facilitate these functions. They serve as nature's plowman and form nature's gift to fulfill the nutritional needs of crops. Vermicomposting appears to be the most promising as high value biofertilizer which not only increases the plant growth and productivity by nutrient supply. It reduces the requirement of more land for disposal of wastes. It helps to create better environment. Thus reduces ecological risk. It results in several benefits to farms, industries, and environment and over all national economy.

\section{Acknowledgements}

We thank the authorities of Sri adi chunchanagiri womens college cumbum for providing lab facilities and to the Department of Biochemistry,Biotechnology.

\section{References}

[1]. C.Darwin, The formation of vegetable mould through the action of worms, with observations on their habitats, Murray, London, (1881),326.

[2]. Arnon.D.I., "Copper enzymes in isolated chloroplast, polyphenol oxidase in Beta vulgaris", Plant Physiol, (1949),24, 1-15.

[3]. R.M Follet, L.S Murphy, R.L Donahne, Fertilizers soil amendments, Prentice hall, (1988), 393-422.

[4]. U.S Bhawalkar and U.V Bhawallkar, Organics in soil Health and Crop production, Peekay Tree crops development foundation cochin, (1993), 69-85.

[5]. Tandon.H.Z., "Methods of analysis of soils, plant, water and Fertilizers". Fertilizer Development and Consultation Organization, New Delhi., (1993), 1-148.

[6]. Baron.J.E., Peterson.R.L and Finegold.M.S., "Cultivation and isolation of viable pathogens". In: Diagnostic microbiology, (1994), 9th Edn., Mosby, London. 
[7]. M.Delgado, H.Bigertego, I.Watter and R.Calbo, Use of California red worm in sewage sludge transformation, Turrialba, (1995), 45, 33-41.

[8]. Kavian.M.F and Ghatnekars., Biology of earthworms, Chappman and Hill, London, (1996),129-47.

[9]. Edwards.C.A., Bohlen.P.J., "Biology and ecology of earthworms (3 edition) Chapman and Hall . London, New York, (1996) ,426.

[10]. G.H.,Williams.P.M.L., Catter.P.J and Long.N.R, Soil. Biol. Biochem, (1997), 29,599- 602. [5]M. A Livan and W .Thompson., NARI Annual Report,(1997).

[11]. M .Gandhi, V. Sangwan, K.K Kapoor and N.Dilbaghi, Composting of household wastes with and without Earthworms, Environment and Ecology ,15(2), (1997), 432-434.

[12]. Ranganathan.L.SandVinotha.S.P., "Influence of pressmud on the enzymatic variations in the different reproductive stages of Eudriluseugeniae",CurrentScience,(1998),74,634-635

[13]. Tanaka.A., I.H., Tanaka.R., Tanaka.N.K., Yoshida.K., Okada.K., "Chlorophyll a oxygenase (CAO) is involved in chlorophyll b formation from chlorophyll a”, Proc. Nat. Acad. Sci. USA, (1998),95, 12719-12723.

[14]. Harborne.J.B., "Phytochemical methods: A guide to modern techniques of plant analysis". 3rd ed. Chapman and Hall,London,(1998),302.

[15]. L.S Ranganathan and S.P Vinoth.,Influence of pressmud on the enzymatic variations in the different reproductive stages of Eudrilus eugeniae, Current Science, (1998), 74,634-635.

[16]. L.S Ranganathan and K.Parthasarathi, Enhanced phosphatase activity in earthworm casts is more of microbial origin, Current Science, 79, (2000), 1158-1159.

[17]. L.S Ranganathan and K.Parthasarathi, Enhanced phosphatase activity in earthworm casts is more of microbial origin, Current Science, (2000), 79,1158-1159.

[18]. Atiyeh.R. M., Subler .S., Edwards.C.A., Bachman.G.,Metzger J. D and Shuster.W., "Effects of vermicomposts and composts on plant growth in horticultural container media and soil", (2000), Pedo biologia, 44, 579-590.

[19]. P.A Ndakidem., F.D Dakora, Legume seed flavonoids and nitrogenous metabolites as signals and protectants in early seedling development, Funct. Plant Biol, 30, (2003),729 -745.

[20]. Kaviraj and S.Sharma, Municipal solid waste management through vermicomposting employing exotic and local species of earthworms, Bioresource Technology, (2003), 90(2), 169- 173.

[21]. S.K.Sujatha, A.Mahalakshmi and R.Shenbaga rathi, Effect of indigenous plants of soil samples, Indian.J. Biotechnology in agriculture and Environment, (2003),345-353.

[22]. [22]K.P.Nagavallemma, S.P.Wani, S.Lacroix, V.V.Padmaja, C.Vineela, M .Babu Rao, K.L.Sahrawat, Vermicomposting: Recycling wastes into valuable organic fertilizer, International Crops Research Institute for the Semi-Arid Tropics(2004), 8, 20.

[23]. Piperseldon,Michael Dapanto, Brent sipes and Kelly.,Dinges, Small scale vermicomposting, Plant and Environmental protection sciences,(2005), 45.

[24]. Komilis D.P and Ham.R.K., Waste management, (2006),26,62-70.

[25]. P. K Padmavathiamma, ., and U.R.Kumari, An experimental study of vermi-biowaste composting for agricultural soil improvement, Bioresource Technology, (2008),99(6), 1672-1681.

[26]. L.Canellas, F.Olivare, Okorokova - A.Facanha, . A.Facanha., Humic acids isolated from earthworm compost enhance root and soil fertility, (2011), 1-23.

[27]. Ananthakrishnasamy.S., Gunasekaran G., Manimegala.G., Sundaramoorthy.P and Murugeswari.S., "Effect of ordinary compost, compost by effective microorganisms and vermicompost from municipal solid waste on the growth and yield of Vigna mungo (L.)'Indian Streams Research Journal,(2013), 3 (2). 